\title{
Sequence-specific DNA binding of the B-cell-specific coactivator OCA-B
}

\author{
Karyn L. Cepek, Daniel I. Chasman, and Phillip A. Sharp ${ }^{1}$ \\ Center for Cancer Research and Department of Biology, Massachusetts Institute of Technology, Cambridge, Massachusetts \\ 02139 USA
}

B-cell-specific transcription of immunoglobulin genes is mediated by the interaction of a POU domain containing transcription factor Oct-1 or Oct-2, with the B-cell-specific coactivator OCA-B (Bob-1, OBF-1) and a prototype octamer element. We find that OCA-B binds DNA directly in the major groove between the two subdomains of the POU domain, requiring both an $A$ at the fifth position of the octamer element and contact with the POU domain. An amino-terminal fragment of OCA-B binds the octamer site in the absence of a POU domain with the same sequence specificity. Coactivator OCA-B may undergo a POU-dependent conformational change that exposes its amino terminus, allowing it to recognize specific DNA sequences in the major groove within the binding site for Oct-1 or Oct-2. The recognition of both the POU domain and the octamer sequence by OCA-B provides a mechanism for differential regulation of octamer sites containing genes by the ubiquitous factor Oct-1.

[Key Words: OCA-B; Oct-1; Oct-2; octamer sequence; cell-type-specific transcriptional regulation; DNA binding]

Received May 23, 1996; revised version accepted July 9, 1996.

Specific gene expression is mediated by the interaction of transcription factors with DNA elements present in promoters and enhancers. However, many transcription factors and their DNA elements have widespread distribution, which leads to a fundamental question: How do ubiquitous components mediate selective gene activation? The octamer motif $\left(5^{\prime}\right.$-ATGCAAAT- $\left.3^{\prime}\right)$ represents a DNA element with widespread distribution. First identified as a conserved motif present in immunoglobulin (Ig) heavy and light chain promoters and enhancers (Falkner and Zachau 1984), the octamer motif was subsequently found in the promoters of many cellular genes including H2B (Sive et al. 1986; Fletcher et al. 1987) and snRNAs (Carbon et al. 1987; Tanaka et al. 1988; Murphy et al. 1989; Yuan and Reddy 1989) (see Fig. 6, below). Although present in diverse genes, a single copy of the octamer element is sufficient to mediate the B-cell-specific expression of heterologous genes expressed from minimal promoter elements (Wirth et al. 1987).

In B cells, the octamer element is bound by Oct-1 and Oct-2 (Singh et al. 1986; Staudt et al. 1986), which share a conserved DNA-binding domain, the POU domain (Herr and Cleary 1995). The POU domain is composed of two structurally independent DNA-binding domains, the POU-specific domain ( $\mathrm{POU}_{\mathrm{S}}$ ) and the homeodomain $\left(\mathrm{POU}_{\mathrm{H}}\right)$, connected by a flexible linker. Both domains bind the major groove but on opposite sides of the DNA (Klemm et al. 1994), with the POU $_{\mathrm{S}}$ domain contacting

\footnotetext{
${ }^{1}$ Corresponding author.
}

the 5'-ATGC subsite and the POU $\mathrm{P}_{\mathrm{H}}$ binding the AAAT$3^{\prime}$ subsite. The amino-terminal arm of the $\mathrm{POU}_{\mathrm{H}}$ contacts the minor groove at the center of the octamer element. No protein-protein contacts are made between the two POU subdomains, but they bind cooperatively even in the absence of the linker. The cooperativity is believed to be mediated partially by overlapping contacts with phosphate groups at the center of the octamer element (Klemm and Pabo 1996).

Because Oct-1 is expressed in a ubiquitous manner and Oct-2 is expressed predominantly in B cells, the latter initially was thought to be responsible for the B-cellspecific function of the octamer element. Subsequent experiments, however, showed that Oct- 1 and Oct- 2 could equivalently activate octamer containing promoters in vitro (LeBowitz et al. 1988; Pierani et al. 1990; Luo et al. 1992) and that cell lines and animals lacking Oct- 2 could still produce Ig (Corcoran et al. 1993; Feldhaus et al. 1993). The B-cell-specific activity of the octamer element was then proposed to be mediated by a B-cell-specific coactivator that interacted with both Oct-1 and Oct-2 and modulated their function (Pierani et al. 1990; Pfisterer et al. 1994).

The recently discovered B-cell-specific coactivator OCA-B binds the POU domain of Oct-1 and Oct- 2 both in solution (Luo and Roeder 1995; Pfisterer et al. 1995) and as a complex with the prototype octamer sequence (Gstaiger et al. 1995; Luo and Roeder 1995; Pfisterer et al. 1995; Strubin et al. 1995). OCA-B is expressed exclusively in cells of the B lymphocyte lineage. In B cells, 
OCA-B is present as two polypeptides of $34 \mathrm{kD}$ and 35 $\mathrm{kD}$, probably attributable to a posttranslational modification, and is rich in proline, serine, and threonine residues. In vitro, OCA-B stimulates Ig but not $\mathrm{H} 2 \mathrm{~B}$ promoters (Luo and Roeder 1995) in spite of identical sequences for the octamer element, implying a role for promoter context in the mechanism of OCA-B stimulation. In vivo, OCA-B in the presence of Oct-1 stimulates the $\mathrm{H} 2 \mathrm{~B}$ promoter two-fold whereas it stimulates an Igא promoter $\sim$ seven-fold (Strubin et al. 1995) and an IgH promoter fifteen-fold (Gstaiger et al. 1995).

The cooperative assembly of multiprotein complexes involving distinct combinations of transcription factors and/or cofactors on adjacent sequence elements is a common theme in differential gene regulation. For example, induction of the immediate early genes of herpes simplex virus $(\mathrm{HSV})$ is mediated by the formation of a complex, termed $\mathrm{Cl}$, composed of Oct-1, the viral regulatory protein VP16 ( $\alpha \mathrm{TIF}, \mathrm{Vmw} 65)$, and the cellular protein HCF (C1) (Kristie and Roizman 1984; Gerster and Roeder 1988; Kristie et al. 1989; Xiao and Capone 1990). Formation of the $\mathrm{Cl}$ complex requires a specific DNA sequence (5'-ATGCTAATGATATT-3') that differs from the prototypic octamer site in two ways. There is a $\mathrm{T}$ at position 5 and an additional 3 '-flanking element, the GARAT motif (5'-GATATT-3'), immediately adjacent to the octamer site.

The precise assembly of this complex on the HSV immediate early promoters is characterized by multiple protein-protein and protein-DNA interactions. The GARAT element is recognized by VP16 but the affinity of this interaction is sufficiently low that assembly of the complex requires additional interactions with both Oct-1 and HCF (Kristie and Sharp 1990). Four residues on the surface of the Oct-l homeodomain are critical for formation of the $\mathrm{Cl}$ complex. Their importance is highlighted by the fact that the closely related Oct- 2 POU homeo domain, which only differs by one of these and six additional residues, cannot form the $\mathrm{C} 1 \mathrm{complex}$ (Pomerantz et al. 1992). The other essential cellular protein HCF ( $\mathrm{Cl}$ ) probably does not contact DNA but interacts with both VP16 and Oct-1. HCF is a large and complex protein that is post-translationally modified by proteolytic cleavage and by phosphorylation (Kristie et al. 1995; Wilson et al. 1995). These modifications may provide further contributions to specific interactions within the $\mathrm{C} 1$ complex or affect the functioning of the $\mathrm{Cl}$ complex.

Thus, the octamer element is involved in the formation of at least two multicomponent, transcriptionally active complexes. Sequences within or adjacent to the octamer motif may contribute to the differential activity of the octamer element in different cell types. Although the recent discovery of OCA-B /Gstaiger et al. 1995; Luo and Roeder 1995; Pfisterer et al. 1995; Strubin et al. 1995) has indicated how a ubiquitous promoter element can be activated in a tissue-specific manner, further levels of control must exist as not all genes containing octamer sites are activated in $B$ cells. We show that OCA-B is a unique type of coactivator that binds DNA in a se- quence-specific fashion and interacts with the POU domain of Oct-1 or Oct-2. The ability of OCA-B to simultaneously contact protein and DNA provides a further level of control which may be a general mechanism of coactivator function.

\section{Results}

OCA-B binds only a subset of octamer elements on the basis of the identity of position 5 and not the sequence of the flanking bases

The B-cell-specific coactivator OCA-B binds the POU domain of Oct-1 and Oct- 2 on the prototype octamer sequence (Gstaiger et al. 1995; Luo and Roeder 1995; Pfisterer et al. 1995; Strubin et al. 1995). However, in a mobility shift analysis using a fragment of the HSV aIE element containing a nonprototype octamer element and additional flanking sequences $\left(5^{\prime}-\mathrm{A}^{1}\right.$ TGCTAATGATA$\mathrm{TT}^{14}-3^{\prime}$ ), an Oct-1 POU domain/OCA-B/DNA complex could not be detected (Fig. 1A, lanes 1-4). This $\alpha$ IE element has been extensively studied and supports the assembly of a multiprotein complex requiring interactions between Oct-1, the viral $\alpha$ TIF (VP16), and an additional cellular factor $\mathrm{Cl}$ (HCF) to form the $\mathrm{Cl}$ complex (Kristie et al. 1989|. To determine whether the nonprototype octamer element bearing a $\mathrm{T}$ at position 5 or the flanking sequences interfered with the formation of the complex, a probe ( $\alpha$ IE-half) containing sequences known to be recognized by only Oct-1 $\left(5^{\prime}-\mathrm{A}^{1}\right.$ TGCTAATGAT $\left.{ }^{11}-3^{\prime}\right)$ was constructed. Although an Oct-1 POU complex formed with this sequence, it did not stably interact with OCA-B (Fig. 1A, lanes 9-12). The $\alpha$ IE octamer sequence differs from the prototype at position $5, \mathrm{~T}$ in place of $\mathrm{A}$. To assess the effect of the nonprototype $\mathrm{T}$ at position 5 on binding, the $\alpha \mathrm{IE}-\mathrm{wt}$ probe was mutated from $\mathrm{T}$ to $\mathrm{A}$ at position 5 ( $5^{\prime}$-ATGCA ${ }^{5}$ AATGATATT-3'). The $\alpha$ IE-(T/A) probe efficiently formed the Oct-1 POU domain/DNA complex, and this complex bound OCA-B resulting in an additional ternary complex of slower mobility (Fig. 1A, lanes 5-8). The same results were obtained using full length Oct-2; OCA-B bound to the Oct-2/DNA complex only on the $\alpha \mathrm{IE}-(\mathrm{T} / \mathrm{A}$ ) probe (data not shown). Thus, formation of a multiprotein/DNA complex involving an octamer site, the POU domain from Oct-1 or Oct-2, and OCA-B requires a specific DNA sequence at the center of the octamer element $\left(5^{\prime}\right.$-ATGCAAAT- $\left.3^{\prime}\right)$. These data suggest that having an $A$ at position 5 as contrasted to $T$ either confers a specific conformation on the POU domain that is competent for OCA-B binding or that OCA-B directly contacts DNA.

In transfection experiments, OCA-B has been shown to activate transcription from the $\mathrm{Ig \kappa}_{\kappa}, \mathrm{IgH}$, and $\mathrm{H} 2 \mathrm{~B}$ promoters (Gstaiger et al. 1995; Strubin et al. 1995) (albeit with different strengths) that have prototype octamer sequences. Probes were prepared containing the prototype element as well as $5^{\prime}$ and $3^{\prime}$ flanking regions of both the IgH and $\mathrm{H} 2 \mathrm{~B}$ promoters. The Oct-1 POU domain efficiently bound OCA-B on both the IgH-wt and H2B-wt probes (Fig. 1B, lanes 1-4 and 9-12). When position 5 

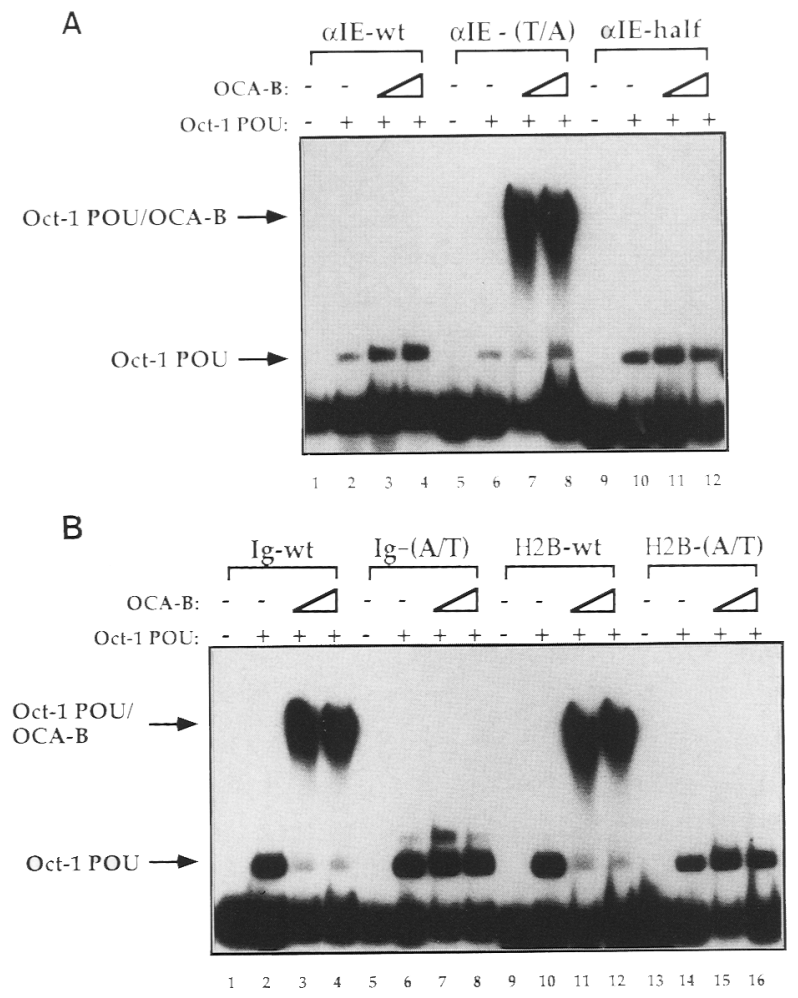

Figure 1. OCA-B distinguishes between octamer elements on the basis of the identity of position 5 and not the sequence of the flanking bases. (A) For EMSA, full-length OCA-B was added at 100 or $200 \mathrm{ng}$ to DNA-binding reactions containing the probe listed at the top of each group of lanes in the presence of the POU domain of Oct -1 (137.5 pg/20 $\mu$ l reaction). The probes used contained either the HSV $\alpha \mathrm{IE}$ wt sequence $15^{\prime}$-GTGCATGCTAATGATATTCTTTGG-3') (Kristie et al. 1989) (lanes $1-4)$, a $\mathrm{T}$ to A mutation at position $5\left(\alpha \mathrm{IE}-(\mathrm{T} / \mathrm{A})=5^{\prime}\right.$-GTGCATGCAAATGATATTCTTTGG -3') (lanes 5-8), or a deletion at the $3^{\prime}$-end ( $\alpha$ IE-half $=5^{\prime}$-GTGCATGCTAATGAT-3') (lanes 9-12). The position of the various protein-DNA complexes are indicated by arrows. $(B)$ Using the same protein concentrations as above, EMSA was performed on parallel DNA-binding reactions containing the probes listed at the top of each group of lanes. The probes contained the following sequences: Ig- $w \mathrm{t}=5^{\prime}$-AATTCACCCTGTCTCATGAATATGCAAATCAGGTGAGTCTATG-3' Ig-(A/T) = 5'-AATTCACCCTGTCTCATGAATATGCTAATCAGGTGAGTCTATG- $3^{\prime}$ H2B-wt $=5^{\prime}$ GATCCTAGAATCGCTTATGCAAATAAGGTGAAGAGTTGAAGTCG-3' H2B-(A/T) = 5'-GATCCTAGAATCGCTTAT GCTAATAAGGTGAAGAGTTGAAGTCG-3'. The sequence of these probes contains the octamer site and immediate flanking regions of the endogenous IgH (Landolfi et al. 1986) and H2B (Pierani et al. 1990) gene promoters.

within the octamer element of each of these probes was mutated from A to T, OCA-B did not bind the Oct-1/ DNA complex (Fig. 1B, lanes 5-8 and 13-16). As anticipated, the POU domain of Oct-1 bound both sites with similar affinities. The same results were obtained when Oct- 2 was tested with these probes (Fig. 2, and data not shown for $\mathrm{IgH}$ ). Thus, formation of a multiprotein Oct-1 or Oct-2/OCA-B/DNA complex involving an octamer site requires a specific DNA sequence at the center of the octamer element $\left(5^{\prime}\right.$-ATGCAAAT- $\left.3^{\prime}\right)$.

$O C A-B$ can bind to an octamer element with separated subsites for the $P O U_{S}$ and $P O U_{H}$ subdomains

The importance of position 5 of the octamer element is apparent in the crystal structure of the Oct-1 POU domain-octamer complex as it is contacted by both the $\mathrm{POU}_{\mathrm{H}}$ and $\mathrm{POU}_{\mathrm{S}}$ domains (Klemm et al. 1994). Each of the POU subdomains can independently bind a subsite of the octamer element flanking position 5. Although the two POU subdomains do not make protein-protein contacts with one another, they are connected by a flexible linker and bind DNA cooperatively (Klemm and Pabo 1996) (see Fig. 3). The cooperativity is believed to be partially mediated by overlapping contacts with phosphate groups at position 5, the same position found to be important for the formation of the Oct- 2 or Oct-1 POU/ OCA-B/DNA complex.

Separation of the subsites by insertion of two base pairs in the middle of the prototype octamer sequence, in a way that retains the base immediately flanking each subsite, lowers the affinity of the POU domain by $\sim 30$ fold and abolishes the cooperativity of the binding of the subdomains (Klemm and Pabo 1996). A ten-fold higher concentration of Oct-1 POU was used to generate a significant level of Oct-1 complexed with DNA on the H2B sequence with separated subsites $\left(5^{\prime}\right.$-ATGCACAAAT$3^{\prime}$ ). Under these conditions, OCA-B was able to bind and produce an Oct-1 POU/OCA-B/DNA complex (Fig. 4A, lanes 4 and 6). This suggests that the contacts needed for OCA-B binding are present even when the POU subdo-

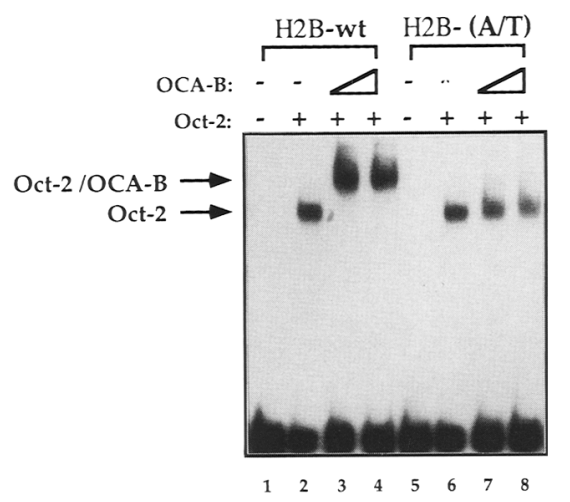

Figure 2. OCA-B forms an Oct-2/OCA-B/DNA complex on octamer sites containing an $A$ but not a $T$ at position 5. DNAprotein binding reactions were carried out as described in Materials and methods. The sequences of the probe DNAs used are listed in the legend to Figure 1B. Full-length Oct-2 was isolated from the human B-cell line, BJAB. Full-length OCA-B containing a six-histidine tag at the carboxyl terminus was used at 100 ng (lanes 3 and 7 ) and $200 \mathrm{ng}$ (lanes 4 and 8 ) per reaction. The position of the Oct-2/DNA and Oct-2/OCA-B/DNA complexes are indicated with arrows. Free probe migrated to the bottom of the gel. 


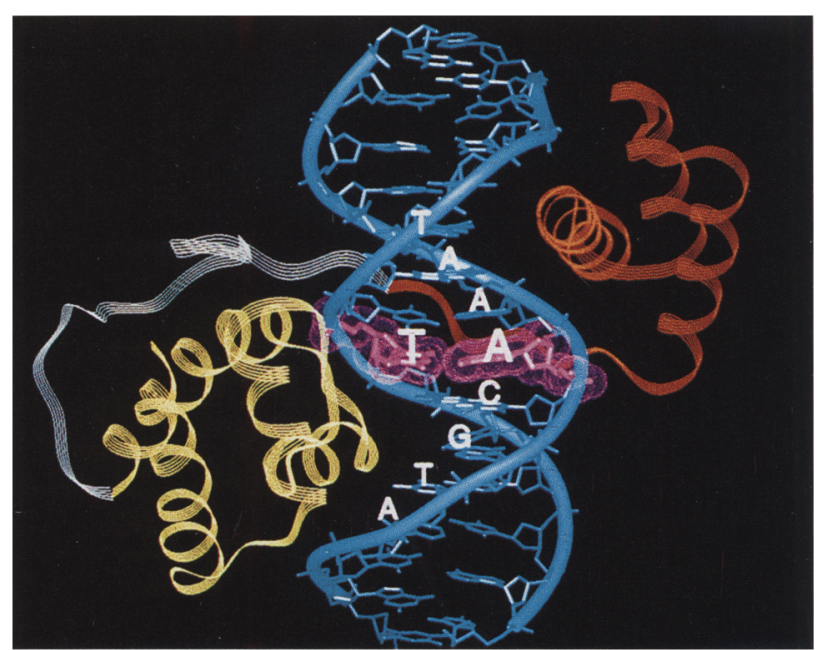

Figure 3. Structure of the Oct-1 POU domain-octamer complex illustrating the A-T base pair at position 5 . The crystal structure of the Oct-1 POU domain-octamer DNA complex is shown (Klemm et al. 1994). The DNA is colored blue and the Van der Waals surface of the A-T base pair at position 5 is highlighted in purple. The $\mathrm{POU}_{\mathrm{H}}$ is shown as a red ribbon, the $\mathrm{POU}_{\mathrm{S}}$ as a yellow ribbon, and the linker connecting the carboxyl terminus of the $\mathrm{POU}_{\mathrm{S}}$ to the amino terminus of the $\mathrm{POU}_{\mathrm{H}}$ is shown in gray. The linker sequence was not ordered in the crystal structure but has been modeled here and is shown to emphasize that the two domains are linked. One strand of the octamer sequence is labeled. This figure was generated with INSIGHT II (Biosym Technologies). Adapted from Klemm and Pabo (1996).

mains are moved apart and no longer influence each others interaction with DNA through contacts with phosphate groups. It is possible that OCA-B predominantly contacts DNA at the center of the octamer element as well as either the $\mathrm{POU}_{\mathrm{S}}$ or $\mathrm{POU}_{\mathrm{H}}$ domain but not necessarily both.

\section{An amino-terminal 118 amino acid fragment of $O C A-B$ can bind DNA in the absence of the POU domain}

The amino-terminal 118 amino acids of OCA-B are fully active in generation of the Oct-1 POU/OCA-B/DNA complex (Strubin et al. 1995). Surprisingly, in the absence of the Oct-1 POU domain, GST-OCA-B $118 \mathrm{~N}$ bound DNA in a sequence specific manner that required an $A$ at position 5 , even when the subsites were separated (Fig. 4B, Fig. 4A, lanes 2 and 8 . A titration of OCA-B $118 \mathrm{~N}$ into DNA-binding reactions containing the $\mathrm{H} 2 \mathrm{~B}$ probe used in Figure $4 \mathrm{~B}$, in the presence or absence of the POU domain of Oct -1 , revealed that the binary complex of OCA-B $118 \mathrm{~N}$ and DNA formed at the same concentration of OCA-B $118 \mathrm{~N}$ as the Oct-1 POU/OCA-B $118 \mathrm{~N} /$ DNA complex (data not shown). This indicates that a major contribution to the affinity of OCA-B $118 \mathrm{~N}$ in the trimolecular complex may result from its interaction with DNA. In addition, protein-protein interactions occur between the amino-terminal domain of OCA-B and the POU domain (Pfisterer et al. 1995; Gstaiger et al. 1996). These interactions may stabilize OCA-B binding in the trimolecular complex. This is supported by the difference in intensity of the OCA-B 118N/DNA complex (Fig. 4A, lane 2) compared to the stronger Oct-1 POU/OCA-B 118N/DNA complex (Fig. 4A, lane 5). Importantly, full-length OCA-B did not bind the octamer element in the absence of the POU domain (Fig. 4A, lanes 3 and 9; data not shown for Ig-wt and Ig-(A/T)]. This suggested that the carboxyl terminus may shield the amino terminus from interaction with DNA.

$O C A-B$ binding requires base contacts in the major groove in the center of the octamer element

The specificity for OCA-B binding A at position 5 and the structure of the POU domain/DNA complex (Fig. 3) led to the prediction that OCA-B contacts DNA in the major groove. To test this hypothesis, two octamer element containing DNA probes from the $\mathrm{H} 2 \mathrm{~B}$ gene were synthesized with modified bases at position 5 . It has been shown that substitution of the A-T base pair at position 5 with A-U results in a four-fold reduction in the binding of the POU domain caused by the loss of a contact between the methyl group in the major groove at position 5 of the $\mathrm{T}$ and Leu55 in the $\mathrm{POU}_{\mathrm{S}}$ domain (Klemm and Pabo 1996). Analysis of the position $5 \mathrm{~A}-\mathrm{U}$ substitution confirmed the reduced affinity of the POU domain; however, when the concentration of POU was increased so that a significant amount of POU domain/ DNA complex was formed, addition of OCA-B at the same concentration as with the prototype element produced a supershifted complex (Fig. 4C). Thus, loss of the major groove methyl group at position 5 by replacing the $T$ with a $U$ did not inhibit OCA-B binding.

Additional modifications substituted the wild-type A-T base pair with an Inosine (I)- 5 methyl (Me) C base pair. This substitution alters the topology of the major groove of DNA without changing the minor groove. In an A-T base pair, the major groove is characterized by a carboxyl group at position 4 of $T$ and an exocyclic amino group at position 6 of $\mathrm{A}$. The I-5MeC substitution inverts these two functional groups. Gel shift analysis using the synthetic $\mathrm{I}-5 \mathrm{MeC}$ probe revealed that the POU domain of Oct-1 bound with an affinity approximately three-fold lower than the wild-type H2B probe (data not shown). Addition of OCA-B to these reactions did not generate a slower mobility complex indicating that this sequence was a very low affinity binding site for OCA-B (Fig. 4A, lanes 7-12). Also, the amino-terminal 118 amino acid fragment of OCA-B did not bind the $\mathrm{I}-5 \mathrm{MeC}$ probe (Fig. 4A, lanes 8 and 11, and Fig. 4B, lanes 10-12). Thus, elimination of the exocyclic amino group at position 6 of adenine, its substitution with a carboxyl group at position 6 of inosine, or the exchange of the carboxyl group at position 4 of thymine with the exocyclic amino 


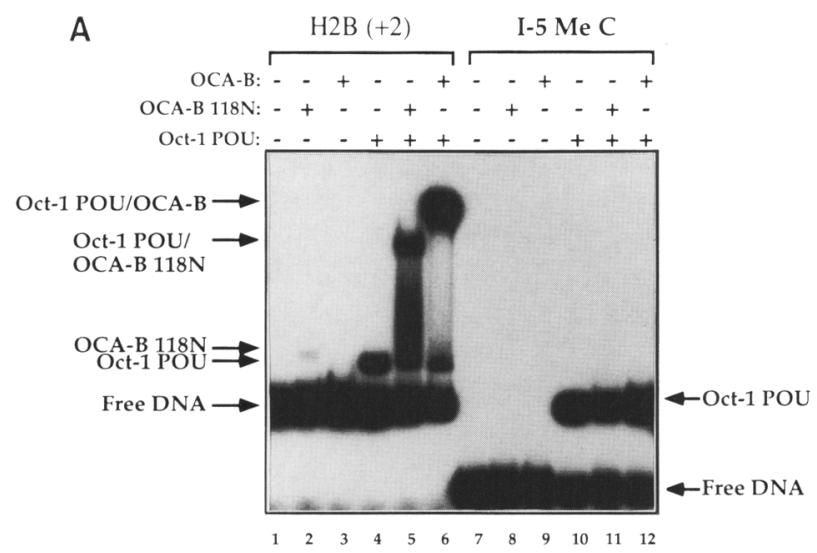

B
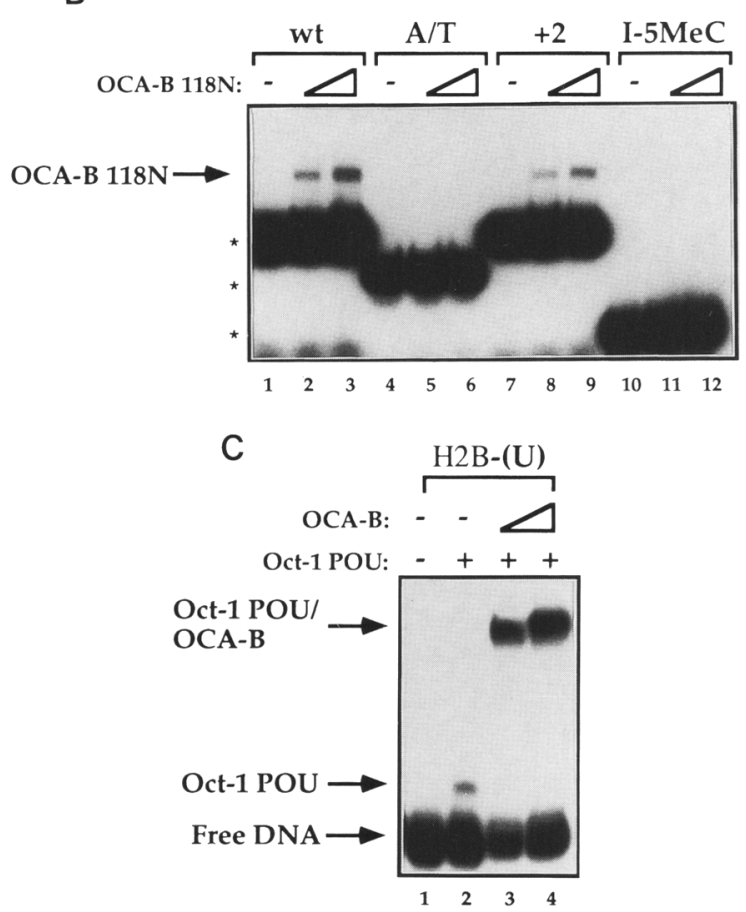

group at position 4 of 5 -methyl cytosine dramatically decreased the binding of both full length OCA-B in an Oct-1 POU/OCA-B/DNA complex, and OCA-B $118 \mathrm{~N}$ in an OCA-B $118 \mathrm{~N} / \mathrm{DNA}$ complex.

OCA-B selectively activates promoters containing an $A$ vs. $T$ at position 5 of the octamer prototype in vivo

To determine whether OCA-B could distinguish A- from $\mathrm{T}$-containing sites in vivo, transient transfection experiments were performed with 293 cells (Fig. 5). Exponentially growing cells were cotransfected with OCA-B and a reporter construct containing two copies of either the prototype octamer site or the position $5 \mathrm{~A}$ to $\mathrm{T}$ mutant upstream of an IgH core promoter followed by the luciferase gene and the SV40 enhancer. Under these conditions in vivo, endogenous Oct-1 protein should permit
Figure 4. OCA-B binding requires base contacts in the major groove in the center of the octamer element. An amino-terminal 118 amino acid fragment of OCA-B can bind this site in the absence of the POU domain. (A) For EMSA, DNA-binding reactions were carried out in $20 \mu \mathrm{l}$ and included the probes labeled at the top of each group of lanes as well as the Oct-1 POU domain $(2.75 \mathrm{ng}$ for $\mathrm{H} 2 \mathrm{~B}(+2)$, and $275 \mathrm{pg}$ for $5 \mathrm{Me} \mathrm{C}-\mathrm{I})$, and full-length GST-OCA-B (250 ng), or GST-OCA-B-118N (500 ng) as indicated. The $\mathrm{H} 2 \mathrm{~B}$ probes used here are based on those constructed by Klemm et al. (1994) and have different flanking sequences and lengths than those used in Figure 1. The 84 base long sequence of one strand of the $\mathrm{H} 2 \mathrm{~B}-\mathrm{wt}$ probe is $5^{\prime}$-AATTCCTGATCAAGATCTGGTCACCCCATGGGCTAGCGCATGCCCAAGGCTGTATGCAAATAAGGACGCGTTCGCGAGGGCCCG-3', and the other strand is complementary. The sequence of the $\mathrm{H} 2 \mathrm{~B}-(+2)$ probe is similar to the $\mathrm{H} 2 \mathrm{~B}-\mathrm{wt}$ probe except that two base pairs have been inserted into the middle of the octamer site $\left(5^{\prime}\right.$-ATGCACAAAT-3 $)$. The sequence of one strand of the H2B derived 5-methyl C-I probe is 5'-TTTTTTGCGCCCAAGGCTGTATGCIAATAAGGACGCGGGGATCCAGG- $3^{\prime}$ and the sequence of the other strand is $5^{\prime}$ GGATCCCCGCGTCCTTATT5MeCGCATACAGCCTTGGGCGC-3', such that the probe length is 47 base pairs. (B) For EMSA, DNA-binding reactions were carried out in $20 \mu \mathrm{l}$ and included the probes labeled at the top of each group of lanes as well as GST-OCA-B 118N (400 or $800 \mathrm{ng}$ ). (*) Position of the free probe. Note that in data not shown, removal of GST from OCA-B $118 \mathrm{~N}$ had no effect on its sequence-specific binding. The sequence of the 70 base long H2B A/T probe is $5^{\prime}$-AATTCCTGGGTCCATGGGCTATGCCCAAGGCTGTATGCTAATAAGGACGCGTTTCGCGAGGGCCCGGATCC-3' . (C) EMSA was performed as above $(275$ pg Oct-1 POU and 100 or $200 \mathrm{ng}$ OCA-B / with a synthetic DNA probe containing an A-U base pair at position 5 . The sequence of one strand of the probe is 5' - TTTTTTGCGCCCATGGGCTAGCGCCTGCCCAAGGCTGTATGCAAATAAGGACGCGT TICGCGAGGGCCCGGGGGATCCAGG-3' and the sequence of the other strand is 5'-GGATCCCCCGGGCCCTCGCGAACGCGTCCTTATTUGCATACAGCCTTGGGCATGCGCTAGCCCATGGGC$\overline{\mathrm{G}} \mathrm{C}-3^{\prime}$ such that the probe length is 84 base pairs.

formation of the Oct-1/OCA-B/DNA complex. Cotransfection of the cells with OCA-B and the A containing reporter resulted in a 4.4-fold increase in luciferase activity over transfection of the reporter in the absence of OCA-B. Neither the T-containing reporter nor an octamer negative reporter were stimulated by cotransfection of OCA-B. These results are consistent with the gel shift analyses and suggest that whereas Oct-1 can bind to octamer sites containing either an $\mathrm{A}$ or a $\mathrm{T}$ at position 5 in vitro, OCA-B only binds to and activates transcription from Oct-1 bound to the A containing prototype octamer site.

\section{Discussion}

OCA-B is a novel type of coactivator in that it contacts DNA, yet its function as a transcriptional coactivator is 


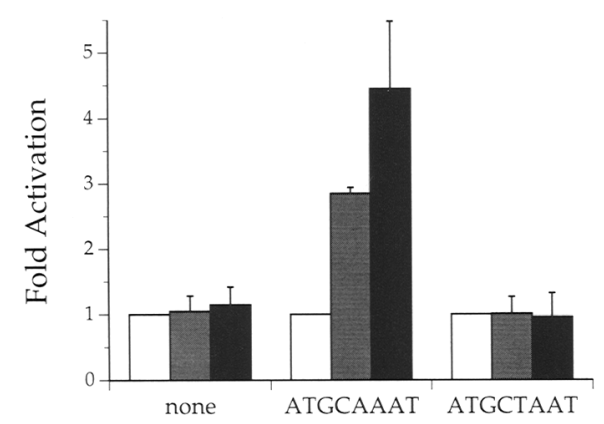

Figure 5. OCA-B distinguishes the presence of $A$ vs. $T$ at position 5 of the octamer prototype in vivo. 293 cells were cotransfected with $5 \mu \mathrm{g}$ of reporter vector, 0 (white), 3 (gray) or $6 \mu \mathrm{g}$ (black) of OCA-B expression vector [pCATCH Bob-1 (Gstaiger et al. 1995)|, $1 \mu \mathrm{g}$ of pCMV $\beta$-gal used as an internal control, and additional empty expression vector, $\mathrm{pRcCMV}$ (Invitrogen), to a total of $20 \mu \mathrm{g}$. Reporter vectors were unaltered or contained two tandem copies of either the octamer element $15^{\prime}$-ATGCAAAT$\left.3^{\prime}\right)$ or the A to T mutation at position 5 (5'-ATGCTAAT-3') followed by the core promoter $\left({ }^{-} 49-{ }^{+} 1\right)$ from the V17.2.25 $\mathrm{IgH}$ gene (Grosschedl and Baltimore 1985), the luciferase gene, and the SV40 enhancer. Fold activation was calculated by dividing the amount of luciferase activity obtained in the presence of OCA-B by the amount of activity obtained in the absence of OCA-B, normalized to $\beta$-galactosidase production, for each reporter construct. Error bars indicate one standard deviation from the mean when the fold activation in three experiments was averaged. Each measurement was performed in duplicate.

dependent upon interactions with Oct-1 (Luo and Roeder 1995). In contrast to the prevailing view that OCA-B binds the POU domain but not the octamer site (Pfisterer et al. 1995; Luo et al. 1995; Strubin et al. 1995; Schubart et al. 1996; Gstaiger et al. 1996), we find that OCA-B directly contacts the major groove in a sequence-specific fashion that requires an $\mathrm{A}$ at position 5 of the octamer element. At the same position, the amino-terminal arm of the $\mathrm{POU}_{\mathrm{H}}$ contacts only the minor groove of the octamer element, leaving the surface of several base pairs flanking the central $A$ accessible in the major groove for contacts by OCA-B (see Fig. 3). This mode of OCA-B binding allows opportunity for simultaneous interactions with either or both of the POU subdomains of Oct 1 .

Intact OCA-B protein does not bind DNA in the absence of the POU domain of Oct-1 or Oct- 2 whereas the amino-terminal 118 fragment does. This suggests that the carboxy-terminal subdomain of OCA-B interferes with the DNA binding of the amino-terminal subdomain. One aspect of the interaction of the amino terminus of OCA-B with the DNA is a simultaneous interaction, possibly of the carboxyl terminus, with the POU domain itself. An interaction of the carboxyl terminus of OCA-B with the POU domain may alter the conformation of OCA-B and expose an amino-terminal DNAbinding surface. Furthermore, these interactions might stabilize an allosteric conformation of OCA-B capable of binding DNA in the major groove. This type of confor- mational change is consistent with the ability of the carboxy-terminal half of OCA-B to stimulate transcription more effectively than the full-length protein in vivo (Pfisterer et al. 1995; Strubin et al. 1995).

Two separate lines of evidence strongly imply that OCA-B binds to specific DNA sequences, and a third experiment supports this conclusion. First, an aminoterminal 118 amino acid fragment of OCA-B binds DNA in the absence of Oct-1. Like the interaction of fulllength OCA-B with the Oct-1/DNA complex, this binding is dependent upon an $\mathrm{A}$ in the fifth position of the octamer element and more specifically on the atomic structure of the major groove at this site. Second, an alteration of the major groove at position 5 of the octamer element from an $\mathrm{A}-\mathrm{T}$ base pair to an $\mathrm{I}-5 \mathrm{MeC}$ base pair does not alter contacts between the Oct-1 POU domain and DNA (Klemm et al. 1994); however, it abolishes the formation of an Oct-1 POU/OCA-B/DNA trimolecular complex. Third, both full-length OCA-B and OCA-B $118 \mathrm{~N}$ can bind to an Oct-1 POU/DNA complex formed on an octamer site containing a two-base-pair insertion at its center which separates the subsites for the $\mathrm{POU}_{\mathrm{S}}$ and $\mathrm{POU}_{\mathrm{H}}$ domains. If OCA-B binds exclusively to the POU domain and not DNA, it is surprising that it is able to bind to the complex of the Oct-1 POU domain on an octamer element where the separation of subsites is expected to alter the relative orientation of the two POU subdomains. This configuration of the POU subdomains would not be expected to support a fixed interaction with OCA-B unless either OCA-B makes direct contacts with the DNA or OCA-B binding requires interaction with only one of the POU subdomains. In addition, OCA-B $118 \mathrm{~N}$ binds to this site in the absence of the Oct-1 POU domain, reinforcing the idea that it makes contacts with the DNA.

We attempted to investigate the affinity of OCA-B $118 \mathrm{~N}$ for an octamer site and for the Oct-1-POU/DNA complex. Direct measurement of the affinity of either complex was hampered by the inability to detect a high level of binding in the electrophoresis mobility shift assays, possibly attributable to dissociation of the complexes during electrophoresis. Nevertheless, the formation of a shifted OCA-B containing protein-DNA complex was saturable. If the saturated level in the gel reflects binding of all of the probe in the binding reaction before electrophoresis, and the amount of probe bound in solution for each amount of OCA-B is proportional to the amount detected in the gel assay, the affinity of OCA-B $118 \mathrm{~N}$ for the octamer site can be estimated to be $500 \mathrm{nM}$. As the activity of the OCA-B protein diminished with time, our calculation may be an overestimate of the concentration of active protein in the binding reactions, and thus an underestimate of the affinity.

Qualitatively, we are able to make several observations concerning the relative affinities of OCA-B $118 \mathrm{~N}$ for DNA alone and for the POU domain/DNA complex. It is clear that the full-length OCA-B protein has a much greater affinity for the POU domain/DNA complex than for the DNA alone. Binding of the full-length protein to an octamer site was undetectable. Similarly GST- 
OCA-B $118 \mathrm{~N}$ showed strong preferential binding to the POU domain-DNA complex over the octamer element alone. In contrast, binding of OCA-B $118 \mathrm{~N}$ was less discriminating. Its preference for the POU domain DNA complex over DNA alone was revealed in gel electrophoresis mobility assays by the formation of equal or more OCA-B 118N/Oct-1 POU/DNA complex than OCA-B $118 \mathrm{~N} / \mathrm{DNA}$ complex. Although these studies emphasize a critical role of OCA-B/DNA interactions, mutational analysis of the Oct-1 POU domain and direct binding of the amino terminus of OCA-B to the Oct-1 POU domain demonstrate the likelihood that protein-protein interactions contribute to the stability of the Oct-1 POU/ OCA-B 118N/DNA complex (Gstaiger et al. 1996). These interactions probably increase the affinity of OCA-B for the POU/DNA complex over the octamer site alone. They are, however, insufficient to overcome the unfavorable interactions between OCA-B and the DNA on octamer sites having a $\mathrm{T}$ at position 5 .

The two POU subdomains bind the octamer site leaving exposed three base pairs in the major groove at its center. Although the full extent of contacts between OCA-B and the DNA are not known, they could involve this entire surface. It has been reported that the dissociation rate of the Oct-1 POU domain from its binding site is not altered by the presence of OCA-B in the complex (Strubin et al. 1995). Although this may seem inconsistent with multivalent interactions provided by contacts of OCA-B to both the POU domain and the DNA, it is not known if POU domain/DNA contacts are unchanged after binding of OCA-B. In fact, the amino terminus of OCA-B may interact with residues in the POU specific domain known to contact DNA /Gstaiger et al. 1996). Thus, the contacts that the POU domain makes with DNA in a POU/DNA complex may be different from those made in a POU/OCA-B/DNA complex. A loss of DNA contacts by the POU-specific domain may be compensated by additional contacts to OCA-B such that the off rate of Oct-1 from DNA is not altered. The precise mode of OCA-B binding cannot yet be understood through relation to any known families of DNAbinding proteins by sequence homology. Thus, OCA-B might represent a novel motif for protein-DNA interactions.

The conservation of adenosine at position 5 of the octamer element and the B-cell-specific expression of the OCA-B coactivator represent complementary aspects of B-cell-specific gene activation. The octamer elements of immunoglobulin genes universally conserve the adenosine at position 5 (Fig. 6), allowing high levels of OCA-B dependent expression of these genes in B cells. Octamer elements with $\mathrm{T}$ at the 5 th position are not to our knowledge present in immunoglobulin genes even though this sequence binds the Oct-1 and Oct- 2 proteins with high affinity. A similar adenosine also is found in the octamer elements associated with ubiquitously expressed genes such as those encoding histone H2B and snRNAs. Expression of these genes in non-B cells and their correct temporal expression in both $\mathrm{B}$ and non-B cells may require additional coactivator proteins, as has been sug-
Octamer Site Position 5 A vs. T

$\begin{array}{ll}\text { Prototype } & \text { ATGCAAAT } \\ \text { Ig heavy chain enhancer } & \text { ATGCAAAT } \\ \text { MOPC 141 heavy chain promoter } & \text { ATGCAAAG } \\ \text { kappa promoter } & \text { ATGCAAAT } \\ \text { V kappa 19A promoter } & \text { ATGCAAAG } \\ \text { histone H2B } & \text { ATGCAAAT } \\ \text { SV40 enhancer } & \text { ATGCAAAG } \\ \text { U2 snRNA } & \text { ATGCAAAT } \\ \text { U6 snRNA } & \text { ATGCAAAT } \\ \text { HLA DR } \alpha & \text { ATGCAAAT } \\ \text { HLA DQ } 3 & \text { ATGCAAAT } \\ & \\ \text { HSV } \alpha I E & \text { ATGCTAAT } \\ \text { U3 } & \text { ATGCTAAT } \\ \text { 7SK } & \text { ATGCTAAT } \\ & \text { ATGCTAAAG } \\ \text { Adenovirus-2 origin } & \text { ATGATAAT } \\ \text { CR2 } & \text { ATGCTAAT }\end{array}$

Figure 6. Compilation of octamer site sequences. Comparison of several octamer sequence motifs grouped on the basis of the identity of the base at position 5 of the prototype sequence $\left(5^{\prime}\right.$-ATGCA ${ }^{5}$ AAT- $\left.3^{\prime}\right)$. Bases which differ from the prototype have been underlined. The octamer site is present in a wide variety of lymphoid specific promoter and enhancer elements such as Ig $\mathrm{V}_{\kappa}$ and $\mathrm{V}_{\mathbf{H}}$ (Falkner and Zachau 1984; Parslow et al. 1984; Mizushima-Sugano and Roeder 1986) and MHC DR $\alpha$ (Sherman et al. 1989), in ubiquitously expressed genes such as histone H2B (Sive et al. 1986), small nuclear RNA (snRNA) U2 (Tanaka et al. 1988), U3 (Yuan and Reddy 1989), and U6 (Carbon et al. 1987), as well as the SV40 enhancer (Falkner et al. 1986), HLA DQ $\beta$ (Miwa and Strominger 1987), HSV $\alpha$ IE (Kristie and Roizman 1984), 7SK (Murphy et al. 1989), CR2 (Christensen et al. 1992), and the Adenovirus-2 origin of replication (Pruijn et al. $1986)$.

gested (Luo and Roeder 1995). In contrast, octamer elements with a $\mathrm{T}$ at position 5 are found in viral genes, snRNAs, and origins of DNA replication, allowing these elements to exploit the activities of Oct-1 or Oct- 2 but evade the regulatory effects of OCA-B in B cells.

It is well established that a complex of Oct-1, HSV $\alpha$ TIF and a cellular factor (HCF) recognizes a subset of octamer sites dependent on specific flanking sequences to activate the transcription of HSV immediate early genes (McKnight et al. 1987; Gerster and Roeder 1988; Preston et al. 1988; Kristie et al. 1989; Kristie and Sharp 1990). Through its interactions with both Oct-1 and the octamer site, OCA-B represents a cellular example of a similar strategy. The OCA-B protein also simultaneously recognizes DNA sequences and makes specific interactions with the POU domain; however, in this case the sequence requirements are particularly compact. OCA-B recognizes sequences between the two subdomains of the POU domain. The ability of a transcriptional coactivator to contact simultaneously specific DNA sequences and a transcription factor may provide a widespread mechanism by which highly related cis-regulatory sites can exist in many genes and still mediate tissue-specific gene activation. 


\section{Materials and methods}

\section{Production of fusion proteins}

Full-length OCA-B was produced as a glutathione S-transferase (GST)-OCA-B-His fusion protein by adding a six-histidine tag to the carboxy-terminus of OCA-B with the polymerase chain reaction (PCR) and cloning in-frame into the $\mathrm{pGEX}-5 \mathrm{X}-3$ vector (Pharmacia). The fusion protein was expressed using standard methods in TOPP3 cells (Stratagene) and purified on glutathione-Sepharose 4B (Pharmacia). Free OCA-B-His was cleaved from the glutathione beads with Factor $X$ a protease (Promega) and full-length OCA-B containing the His tag at the carboxyterminus was purified on $\mathrm{Ni}^{+2}$ agarose (Qiagen). The protein was eluted with $250 \mathrm{~mm}$ imidazole in $20 \mathrm{~mm}$ HEPES, $5 \mathrm{~mm}$ 2 - $\mathrm{Me}, 100 \mathrm{~mm} \mathrm{KCl}, 0.1 \% \mathrm{NP} 40$, and $20 \%$ glycerol.

Recombinant Oct-1-POU was produced as a GST-fusion (Klemm et al. 1994). Briefly, following affinity chromatography on glutathione-Sepharose and cleavage from the matrix, the Oct-1 POU domain was further purified on a DNA-cellulose column in $0.05 \mathrm{M}$ Tris at $\mathrm{pH} 8.0,0.15 \mathrm{M} \mathrm{NaCl}, 1 \mathrm{mM}$ EDTA, and $5 \mathrm{~mm}$ dithiolthreitol (DTT). The column was washed with 0.05 $\mathrm{M}$ HEPES at $\mathrm{pH} 7.5,0.05 \mathrm{M} \mathrm{NaCl}$, and $0.01 \mathrm{M}$ DTT, and the protein was eluted in the same buffer with $0.25 \mathrm{M} \mathrm{NaCl}$. The protein was then dialyzed against double-distilled water and concentrated by lyophilization.

A vector expressing GST-OCA-B $118 \mathrm{~N}$ was constructed by inserting a PCR product encoding the first 118 amino acids of OCA-B into a modified pGEX-5X-3 vector (Pharmacia) such that sequences encoding the initiator methionine of OCA-B were juxtaposed directly with sequences encoding the four amino acids of the Factor Xa cleavage site. The fusion protein was expressed in BL21 cells grown in minimal media at room temperature, and purified on glutathione-Sepharose 4B (Pharmacia). GST-OCA-B $118 \mathrm{~N}$ was eluted with $10 \mathrm{~mm}$ reduced glutathione in $50 \mathrm{~mm}$ Tris at $\mathrm{pH} 8.0,1 \mathrm{~mm}$ DTT, $1 \mathrm{~mm}$ EDTA, 100 $\mathrm{mM} \mathrm{KCl}$, and $10 \%$ glycerol.

\section{Electrophoretic mobility shift assays}

DNA-protein binding reactions contained 0.5-1.0 ng of DNA probe, $400 \mathrm{ng}$ of poly $[\mathrm{d}(\mathrm{I}-\mathrm{C})] /$ poly[d(I-C)], $50 \mathrm{ng}$ salmon sperm DNA, $10 \mathrm{~mm}$ HEPES at $\mathrm{pH} 7.9,0.5 \mathrm{~mm}$ EDTA, $66.7 \mathrm{~mm} \mathrm{KCl}$, $0.75 \mathrm{~mm}$ DTT, $4 \%$ Ficoll- $400,300 \mu \mathrm{g} / \mathrm{ml}$ BSA and the appropriate amount of purified proteins listed in the figure legends in a total volume of $20 \mu \mathrm{l}$. Reactions lacking the DNA probe were incubated for $15 \mathrm{~min}$ at room temperature prior to addition of the probe and subsequent incubation for an additional $20 \mathrm{~min}$ before the complexes were resolved on $4 \%$ (Oct-2), $6 \%$ (Oct-1 POU), or $11 \%$ (OCA-B $118 \mathrm{~N}$ ) nondenaturing polyacrylamide gels using Tris-glycine electrophoresis buffer.

\section{Transient transfection}

293 cells were transfected by calcium phosphate precipitation with a glycerol shock using standard procedures (Ausubel et al. 1994). Reporter vectors were constructed by first cloning DNA fragments containing $K p n I$ and $X h o I$ restriction sites and two copies of the indicated octamer sequence separated by a PstI site into the pGL2 enhancer vector (Promega). Next, the V17.2.25 $\mathrm{IgH}$ gene core promoter was inserted downstream of the octamer sequences by cloning into the XhoI and HindIII sites. Luciferase activity was measured at $48 \mathrm{hr}$ with $40 \mu \mathrm{l}$ of a $100 \mu \mathrm{l}$ total extract per $10-\mathrm{cm}$ plate using $150 \mu$ l Luciferase Assay Reagent (Promega) and a ML2250 Luminometer (Dynatech Laboratories, Chantilly, VA) with the enhanced flash program and integration for $20 \mathrm{~s}$ with no delay. $\beta$-gal production was mea- sured by incubating $2 \mu \mathrm{l}$ of cell extract with the CPRG substrate (Boehringer Mannheim) in $\mathrm{NaPO}_{4}$ buffer in the presence of $\mathrm{MgCl}_{2}$ and $\beta$-mercaptoethanol for $10 \mathrm{~min}$ at $37^{\circ} \mathrm{C}$, stopping the reaction with $0.055 \mathrm{M} \mathrm{Na}_{2} \mathrm{CO}_{3}$, and determining the $\mathrm{OD}$ at 574 $\mathrm{nm}$ of the resulting solution.

\section{Acknowledgments}

We thank C.O. Pabo and J.D. Klemm for the H2B uracil containing probe, purified Oct-1 POU domain, and helpful discussions, W. Schaffner for the pCATCH-Bob-l construct, J. Kim, J.D. Klemm, P. McCaw, J. Pomerantz and M. Smith for critical reading of the manuscript, $M$. Siafaca for all her support and $M$. Beddall, R. Issner, and Y. Qiu for technical assistance. This work was supported by U.S. Public Health Service grant P01cA42063 from the National Cancer Institute (NCI), National Institutes of Health, by cooperative agreement; CDR-8803014 from the National Science Foundation to P.A.S. and, partially, by NCI Cancer Center Support core grant P30-cA14051. K.L.C. is supported by the Cancer Research Fund of the Damon Runyon-Walter Winchell Foundation Fellowship (DRG-1324). D.I.C. is supported by the Massachusetts division of the American Cancer Society.

The publication costs of this article were defrayed in part by payment of page charges. This article must therefore be hereby marked "advertisement" in accordance with 18 USC section 1734 solely to indicate this fact.

\section{Note added in review}

During review of this manuscript, Gstaiger et al. (1996) independently reported that formation of an Oct-1 or Oct-2 POU domain/OCA-B/DNA ternary complex occurs when an A but not a $T$ is present at position 5 of the octamer element. In addition, they report that a fragment of OCA-B containing the amino-terminal 65 amino acids of OCA-B interacts with the POU domain via protein-protein interactions. They identify residues in the POU-specific domain close to the major groove at position 5 of the octamer site which, when mutated eliminate formation of the ternary complex in a gel shift assay. They suggest that loss of the ternary complex occurs because these mutations abolish protein-protein contacts between OCA-B and the POU domain; however, this need not be the case. It remains possible that the critical mutations in the POU-specific domain alter more than protein-protein interactions. In particular, conformational alterations may occur in the POU domain because of the mutational changes such that different DNA moieties are exposed in the major groove at the center of the octamer element. Such alterations could abolish formation of the ternary complex by obscuring moieties used by OCA-B to contact DNA.

\section{References}

Ausubel, F.M., R. Brent, R.E. Kingston, D.D. Moore, J.G. Seidman, J.A. Smith, and K. Struhl. 1994. Current protocols in molecular biology, vol. 1, pp. 9.0.5-9.0.9. Wiley Greene, New York, NY.

Carbon, P., S. Murgo, J.P. Ebel, A. Krol, G. Tebb, and I.W. Mattaj. 1987. A common octamer motif binding protein is involved in the transcription of the U6 snRNA by RNA polymerase III and U2 snRNA by RNA polymerase II. Cell 51: 71-79.

Christensen, S.M., B.K. Martin, S.S. Tan, and J.H. Weis. 1992. Identification of sites for distinct DNA binding proteins in- 
cluding Oct-1 and Oct-2 in the $\mathrm{Cr} 2$ gene. I. Immunol. 148: $3610-3617$.

Corcoran, L.M., M. Karvelas, G.J. Nossal, Z.S. Ye, T. Jacks, and D. Baltimore. 1993. Oct-2, although not required for early B-cell development, is critical for later B-cell maturation and for postnatal survival. Genes \& Dev. 7: 570-582.

Falkner, F.G. and H.G. Zachau. 1984. Correct transcription of an immunoglobulin $\kappa$ gene requires an upstream fragment containing conserved sequence elements. Nature 310: $71-$ 74.

Falkner, F.G., R. Mocikat, and H.G. Zachau. 1986. Sequences closely related to an immunoglobulin gene promoter/enhancer element occur also upstream of other eukaryotic and of prokaryotic genes. Nucleic Acids Res. 14: 8819-8827.

Feldhaus, A.L., C.A. Klug, K.L. Arvin, and H. Singh. 1993. Targeted disruption of the Oct- 2 locus in a B cell provides genetic evidence for two distinct cell type-specific pathways of octamer element-mediated gene activation. EMBO $I$. 12: $2763-2772$.

Fletcher, F.G., N. Heintz, and R.G. Roeder. 1987. Purification and characterization of OTF-1, a transcription factor regulating cell cycle expression of a histone $\mathrm{H} 2 \mathrm{~b}$ gene. Cell 51: 773-781.

Gerster, T. and R.G. Roeder. 1988. A herpesvirus trans-acting protein interacts with transcription factor OTF-1 and other cellular proteins. Proc. Natl. Acad. Sci. 85: 6347-6351.

Grosschedl, R. and D. Baltimore. 1985. Cell-type specificity of immunoglobulin gene expression is regulated by at least three DNA sequence elements. Cell 41: 885-897.

Gstaiger, M., L. Knoepfel, O. Georgiev, W. Schaffner, and C.M. Hovens. 1995. A B-cell coactivator of octamer-binding transcription factors. Nature 373: 360-362.

Gstaiger, M., O. Georgiev, H. van Leeuwen, P. van der Vliet, and W. Schaffner. 1996. The B cell coactivator Bobl shows DNA sequence-dependent complex formation with Oct-1/Oct-2 factors, leading to differential promoter activation. EMBO $\%$. 15: 2781-2790.

Herr, W. and M.A. Cleary. 1995. The POU domain: Versatility in transcriptional regulation by a flexible two-in-one DNAbinding domain. Genes \& Dev. 9: 1679-1693.

Klemm, J.D. and C.O. Pabo. 1996. Oct-1 POU domain-DNA interactions: Cooperative binding of isolated subdomains and effects of covalent linkage. Genes \& Dev. 10: 27-36.

Klemm, J.D., M.A. Rould, R. Aurora, W. Herr, and C.O. Pabo. 1994. Crystal structure of the Oct-1 POU domain bound to an octamer site: DNA recognition with tethered DNA-binding modules. Cell 77: 21-32.

Kristie, T.M. and B. Roizman. 1984. Separation of sequences defining basal expression from those conferring alpha gene recognition within the regulatory domains of herpes simplex virus $1 \propto$ genes. Proc. Natl. Acad. Sci. 81: 4065-4069.

Kristie, T.M. and P.A. Sharp. 1990. Interactions of the Oct-1 POU subdomains with specific DNA sequences and with the HSV atrans-activator protein. Genes \& Dev. 4: 23832396.

Kristie, T.M., J.H. LeBowitz, and P.A. Sharp. 1989. The octamerbinding proteins form multi-protein-DNA complexes with the HSV $\alpha$ TIF regulatory protein. EMBO J. 8: 4229-4238.

Kristie, T.M., J.L. Pomerantz, T.C. Twomey, S.A. Parent, and P.A. Sharp. 1995. The cellular Cl factor of the herpes simplex virus enhancer complex is a family of polypeptides. $/$. Biol. Chem. 270: 4387-4394.

Landolfi, N.F., J.D. Capra, and P.W. Tucker. 1986. Interaction of cell-type-specific nuclear proteins with immunoglobulin $\mathrm{VH}$ promoter region sequences. Nature 323: 548-551.

LeBowitz, J.H., T. Kobayashi, L. Staudt, D. Baltimore, and P.A.
Sharp. 1988. Octamer-binding proteins from B or HeLa cells stimulate transcription of the immunoglobulin heavy-chain promoter in vitro. Genes \& Dev. 2: 1227-1237.

Luo, Y. and R.G. Roeder. 1995. Cloning, functional characterization, and mechanism of action of the B- cell-specific transcriptional coactivator OCA-B. Mol. Cell. Biol. 15: 41154124.

Luo, Y., H. Fujii, T. Gerster, and R.G. Roeder. 1992. A novel B cell-derived coactivator potentiates the activation of immunoglobulin promoters by octamer-binding transcription factors. Cell 71: 231-241.

McKnight, J.L.C., T.M. Kristie, and B. Roizman. 1987. The binding of the virion protein mediating $\alpha$ gene induction in herpes simplex virus 1 infected cells to its cis site requires cellular proteins. Proc. Natl. Acad. Sci. 84: 7061-7065.

Miwa, K. and J.L. Strominger. 1987. The HLA-DQ $\beta$ gene upstream region contains an immunoglobulin-like octamer motif that binds cell-type specific nuclear factors. Nucleic Acids Res. 15: 8057-8067.

Mizushima-Sugano, J. and R.G. Roeder. 1986. Cell-type-specific transcription of an immunoglobulin $\kappa$ light chain gene in vitro. Proc. Natl. Acad. Sci. 83: 8511-8515.

Murphy, S., A. Pierani, C. Scheidereit, M. Melli, and R.G. Roeder. 1989. Purified octamer binding transcription factors stimulate RNA polymerase III-mediated transcription of the 7SK RNA gene. Cell 59: 1071-1080.

Parslow, T.G., D.L. Blair, W.J. Murphy, and D.K. Granner. 1984. Structure of the $5^{\prime}$ ends of immunoglobulin genes: A novel conserved sequence. Proc. Natl. Acad. Sci. 91: 2650-2654.

Pfisterer, P., A. Annweiler, C. Ullmer, L.M. Corcoran, and T. Wirth. 1994. Differential transactivation potential of Octl and Oct 2 is determined by additional B cell-specific activities. EMBO \% 13: 1655-1663.

Pfisterer, P., S. Zwilling, J. Hess, and T. Wirth. 1995. Functional characterization of the murine homolog of the B cell-specific coactivator BOB.1/OBF.1. I. Biol. Chem. 270: 29870-29880.

Pierani, A., A. Heguy, H. Fujii, and R.G. Roeder. 1990. Activation of octamer-containing promoters by either octamerbinding transcription factor 1 (OTF-1) or OTF-2 and requirement of an additional B-Cell-specific component for optimal transcription of immunoglobulin promoters. Mol. Cell. Biol. 10: 6204-6215.

Pomerantz, J.L., T.M. Kristie, and P.A. Sharp. 1992. Recognition of the surface of a homeo domain protein. Genes \& Dev. 6: 2047-2057.

Preston, C.M., M.C. Frame, and M.E.M. Campbell. 1988. A complex formed between cell components and an HSV structural polypeptide binds to a viral immediate early gene regulatory DNA sequence. Cell 52: 425-434.

Pruijn, G.J., W. van Driel, and P.C. van der Vliet. 1986. Nuclear factor III, a novel sequence-specific DNA-binding protein from HeLa cells stimulating adenovirus DNA replication. Nature 322: 656-659.

Schubart, D.B., P. Sauter, S. Massa, E.M. Friedl, H. Schwarzenbach, and P. Matthias. 1996. Gene structure and characterization of the murine homologue of the B cell-specific transcriptional coactivator OBF-1. Nucleic Acids Res. 24: 1913 1920.

Sherman, P.A., P.V. Basta, A. Heguy, M.K. Wloch, R.G. Roeder, and J.P.Y. Ting. 1989. The octamer motif is a B lymphocytespecific regulatory element of the HLA DR $\alpha$ gene promoter. Proc. Natl. Acad. Sci. 86: 6739-6743.

Singh, H., R. Sen, D. Baltimore, and P.A. Sharp. 1986. A nuclear factor that binds to a conserved sequence motif in transcriptional control elements of immunoglobulin genes. Nature 319: 154-158. 


\section{Cepek et al.}

Sive, H.L., N. Heintz, and R.G. Roeder. 1986. Multiple sequence elements are required for maximal in vitro transcription of a human histone H2b gene. Mol. Cell. Biol. 6: 3329-3340.

Staudt, L.M., H. Singh, R. Sen, T. Wirth, P.A. Sharp, and D. Baltimore. 1986. A lymphoid-specific protein binding to the octamer motif of immunoglobulin genes. Nature 323: 640 643.

Strubin, M., J.W. Newell, and P. Matthias. 1995. OBF-1, a novel B cell-specific coactivator that stimulates immunoglobulin promoter activity through association with octamer-binding proteins. Cell 80: 497-506.

Tanaka, M., U. Grossniklaus, W. Herr, and N. Hernandez. 1988. Activation of the U2 snRNA promoter by the octamer motif defines a new class of RNA polymerase II enhancer elements [published erratum appears in Genes \& Dev. (1989) 3: 584]. Genes \& Dev. 2: 1764-1778.

Wilson, A.C., J.E. Parrish, H.F. Massa, D.L. Nelson, B.J. Trask, and W. Herr. 1995. The gene encoding the VP16-accessory protein HCF (HCFC1) resides in human Xq28 and is highly expressed in fetal tissues and the adult kidney. Genomics 25: 462-468.

Wirth, T., L. Staudt, and D. Baltimore. 1987. An octamer oligonucleotide upstream of a TATA motif is sufficient for lymphoid-specific promoter activity. Nature 329: 174-178.

Xiao, P. and J.P. Capone. 1990. A cellular factor binds to the herpes simplex virus type 1 transactivator Vmw65 and is required for Vmw65-dependent protein-DNA complex assembly with Oct-1. Mol. Cell. Biol. 10: 4974-4977.

Yuan, Y. and R. Reddy. 1989. Genes for human U3 small nucleolar RNA contain highly conserved flanking sequences. Biochim. Biophys. Acta 1008: 14-22. 


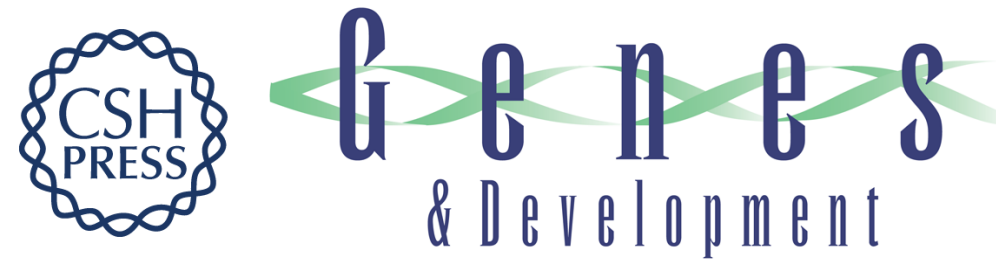

\section{Sequence-specific DNA binding of the B-cell-specific coactivator OCA-B.}

K L Cepek, D I Chasman and P A Sharp

Genes Dev. 1996, 10:

Access the most recent version at doi:10.1101/gad.10.16.2079

References This article cites 44 articles, 19 of which can be accessed free at:

http://genesdev.cshlp.org/content/10/16/2079.full.html\#ref-list-1

License

Email Alerting

Service

Receive free email alerts when new articles cite this article - sign up in the box at the top right corner of the article or click here.

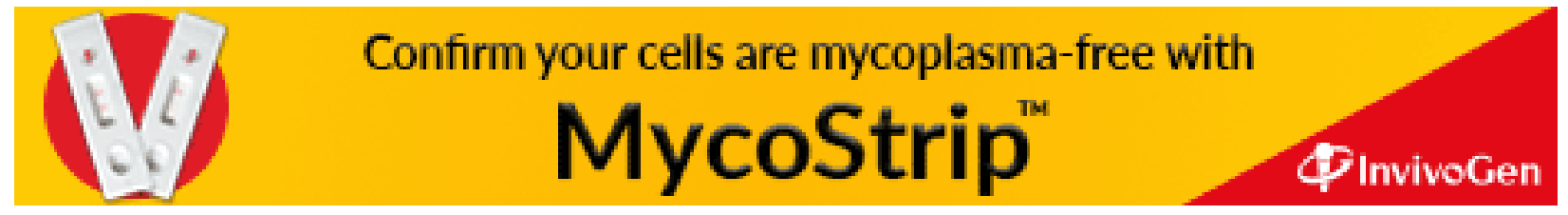

